OPEN ACCESS

Edited by:

Rob Harcourt,

Macquarie University, Australia

Reviewed by:

Alana Grech,

ARC Centre of Excellence for Coral

Reef Studies, Australia

Daniel Paul Costa,

University of California, Santa Cruz,

United States

*Correspondence:

Mark P. Simmonds

mark.simmonds@sciencegyre.co.uk

Specialty section:

This article was submitted to

Marine Megafauna

a section of the journal

Frontiers in Marine Science

Received: 14 October 2020 Accepted: 06 January 2021

Published: 04 February 2021

Citation:

Carlén I, Nunny $L$ and Simmonds MP (2021) Out of Sight, Out of Mind: How Conservation Is Failing European Porpoises. Front. Mar. Sci. 8:617478. doi: 10.3389/fmars.2021.617478

\section{Out of Sight, Out of Mind: How Conservation Is Failing European Porpoises}

\author{
Ida Carlén ${ }^{1,2}$, Laetitia Nunny ${ }^{3}$ and Mark P. Simmonds ${ }^{4,5 *}$ \\ ${ }^{1}$ Coalition Clean Baltic, Uppsala, Sweden, ${ }^{2}$ Department of Zoology, Stockholm University, Stockholm, Sweden, ${ }^{3}$ Wild Animal \\ Welfare, Barcelona, Spain, ${ }^{4}$ School of Veterinary Science, University of Bristol, Bristol, United Kingdom, ${ }^{5}$ Humane Society \\ International, London, United Kingdom
}

The conservation of harbor porpoises (Phocoena phocoena) appears to be failing in Europe. There are particular concerns about this species in the Baltic Proper, Black, and Mediterranean Seas, as well as in the Northeast Atlantic, including the Iberian population, off the Spanish and Portuguese coasts. The Baltic Proper porpoise is "critically endangered," with a population only in the low hundreds, and the Scientific Committee of the International Whaling Commission has repeatedly called for action to ensure its survival. In 2020, the Committee issued a series of recommendations relating to it and the Iberian population. Similarly, the Black Sea harbor porpoise, Phocoena phocoena ssp. relicta, is classified by the IUCN as endangered. Another population which may be genetically distinct is the West Greenland harbor porpoise, which is hunted without quotas or close seasons. European cetaceans and their habitats are covered by a number of international and regional conventions and agreements and, under European Union law, are "highly protected." In practice, however, these legal protections have failed to generate effective conservation. For example, Special Areas of Conservation (SACs) are required for them and, although sites have been designated in some marine areas/countries, in the absence of appropriate management plans, SACs cannot be expected to help improve the harbor porpoise's conservation status. Compared to many other species, porpoises are relatively long-lived with low reproductive capacity and only poor public recognition. Conservation and management efforts are caught up in a complicated nexus of interactions involving a web of commitments under international conventions and agreements, European environmental laws, and European fisheries policy. However, public disinterest, lack of political will to implement conservation measures, and complicated fishing-related issues hinder any real progress. More positively, recent advice from the International Council for the Exploration of the Seas (ICES) provides a new scientific foundation for conservation action to address fisheries bycatch in the Baltic Proper harbor porpoise population. Populations of other porpoise species (family Phocoenidae) are also threatened, most notably the global population of the critically endangered vaquita, or Gulf of California porpoise (Phocoena sinus). The common threats and factors affecting porpoise populations are discussed and recommendations offered.

Keywords: harbor porpoise, porpoise, bycatch, Phocoena, Baltic, vaquita, conservation 


\section{INTRODUCTION}

Porpoises are aquatic mammals in the family Phocoenidae. Globally, seven species of porpoises are recognized by the Society for Marine Mammalogy's (SMM) Committee on Taxonomy ${ }^{1}$. Of these, three (Phocoena phocoena, Neophocaena asiaeorientalis, and Phocoenoides dalli) also have recognized subspecies. This paper focuses on the harbor porpoise ( $P$. phocoena) which has the following subspecies: P.p. phocoena (Atlantic harbor porpoise), P.p. vomerina (Pacific harbor porpoise), and P.p. relicta (Black Sea harbor porpoise). Proposals have been made to recognize porpoises from Iberia and Mauritania as a separate subspecies P.p. meridionalis (Fontaine, 2016) ${ }^{1}$. There may also be a genetically distinct subspecies in West Greenland (Nielsen et al., 2018; NAMMCO, 2019).

The International Union for Conservation of Nature (IUCN) Red List of Threatened Species classifies the risk of extinction to species which have been evaluated by dividing them into categories: Data Deficient (DD), Least Concern (LC), Near Threatened (NT), Vulnerable (VU), Endangered (EN), Critically Endangered (CR), Extinct in the Wild (EW), and Extinct (EX) ${ }^{2}$. Species listed as VU, EN, or CR are considered threatened with extinction. The IUCN has assessed the seven species of porpoises (including two subpopulations for the harbor porpoise) and two subspecies (P.p. relicta and N.a. asiaeorientalis). Three of them are $\mathrm{CR}$, two are $\mathrm{EN}$, two are $\mathrm{VU}$, one is $\mathrm{NT}$, and three are $\mathrm{LC}$ (see Table 1). The IUCN assessment for harbor porpoises on the global scale was recently updated (19th May 2020) and its Red List category is LC (the status it was given in 2008) (Braulik et al., 2020). Global abundance is estimated at over a million, but it is "unknown" whether the global population trend is increasing, decreasing or stable. This global assessment does not reflect more regional assessments.

The latest developments related to conservation of the harbor porpoise in Europe provide the focus of this paper. In European waters the harbor porpoise is considered threatened and classified as VU, the Black Sea subspecies (P.p. relicta) is EN and the Baltic Proper subpopulation of $P$. phocoena has the highest threatened status of CR (IUCN, 2007; Birkun and Frantzis, 2008; Hammond et al., 2008). All three are considered to be "decreasing." It should be noted, however, that as these last three assessments were all carried out over 10 years ago, they are officially out of date and P.p. relicta is currently being reassessed (ACCOBAMS, 2020b) ${ }^{3}$.

The harbor porpoise is a small cetacean with a rotund body, rounded head with no beak, a triangular dorsal fin and short, rounded flippers (Evans, 2020; See Figure 1). There have been several reviews of harbor porpoise biology (for e.g., Bjørge and Donovan, 1995; Learmonth et al., 2014; IAMMWG et al., 2015). Harbor porpoises have shorter gestation, lactation periods and lifespans than most other cetaceans (Braulik et al., 2020). Previously thought to be a mainly coastal species, the harbor porpoise has recently been found in deep North Atlantic waters

\footnotetext{
${ }^{1}$ https://marinemammalscience.org/species-information/list-marine-mammalspecies-subspecies/

${ }^{2}$ https://www.iucnredlist.org

${ }^{3}$ https://www.iucnredlist.org/assessment/process
}

during the winter (Nielsen et al., 2018). They can swim long distances and are generally believed to return to their place of birth to give birth and mate (Kinze, 1990). Males are slightly smaller than females at the same age (with asymptotic body lengths in the North Atlantic of $158-160 \mathrm{~cm}$ and $144-146 \mathrm{~cm}$, respectively, Cervin et al., 2020). They usually live in small fluid groups of 1 to 10 individuals and are generally regarded as shy and undemonstrative, keeping away from boats, and people (Teilmann and Sveegaard, 2019). They have a maximum life expectancy of $\sim 24$ years and an average life expectancy of between 14 and 15 years (Lockyer, 1995). The main period for mating and calving usually occurs between May and August, gestation lasts $\sim 10-11$ months and lactation 8-11 months (IAMMWG et al., 2015). The species is found in temperate and subarctic waters in the northern hemisphere in both the Atlantic and Pacific Oceans (IAMMWG et al., 2015; Evans, 2020).

There are some 16 distinct populations of harbor porpoise in the North Atlantic region (Evans, 2020). They are the smallest but also the most common and widely distributed cetacean in Europe: from Greenland in the west to the Baltic Sea in the east, from the Barents Sea and Iceland in the north, south to the coasts of France and the Iberian peninsula and with a separate, isolated population in the Black Sea. It is a native species in at least 24 European countries.

\section{CURRENT STATUS OF EUROPE'S PORPOISES}

\section{Relevant International Legislation}

Whilst the global status of the harbor porpoise is classified as LC by the IUCN (Braulik et al., 2020), its vulnerability has been recognized in Europe and the species is included in Annex II of the European Union (EU) Habitats Directive ${ }^{4}$. As such it requires strict protection, including the designation of Special Areas of Conservation (SACs) by Member States. $\mathrm{EU}$ nations are required to maintain cetacean populations at a "favorable conservation status" and, therefore, populations need to be appropriately monitored to allow this to be evaluated. The populations in the North and Baltic Seas are included in Appendix II of the Convention on the Conservation of Migratory Species of Wild Animals (CMS). Other European legislation also has a bearing on harbor porpoise conservation, including the EU Common Fisheries Policy (CFP) and the EU Marine Strategy Framework Directive (MSFD). The two CMS daughter agreements focused on cetaceans are also highly relevant: the Agreement on the Conservation of Small Cetaceans of the Baltic, North East Atlantic, Irish and North Seas (ASCOBANS) - which hosts three action/recovery plans for harbor porpoises ${ }^{5}$ and the Agreement on the Conservation of Cetaceans of the Black Sea, Mediterranean Sea and contiguous Atlantic Area (ACCOBAMS); See Table 2 for a summary.

\footnotetext{
${ }^{4}$ https://eur-lex.europa.eu/legal-content/EN/TXT/?uri=CELEX:31992L0043 ${ }^{5}$ Conservation Plan for Harbor Porpoises (Phocoena phocoena L.) in the North Sea, Conservation Plan for the Harbor Porpoise Population in the Western Baltic, the Belt Sea and the Kattegat and Recovery Plan for Baltic Harbor Porpoises: https://www.ascobans.org/en/documents/action-plans.
} 
TABLE 1 | IUCN Red List data relating to porpoises including previous assessment category, current Red List category, Red List criteria, and population trend.

\begin{tabular}{|c|c|c|c|c|c|c|c|c|}
\hline Common name & Scientific name & Region & Previous & sessment* & $\begin{array}{l}\text { Most recent } \\
\text { assessment }\end{array}$ & $\begin{array}{l}\text { Red list } \\
\text { category* }\end{array}$ & Red list criteria** & $\begin{array}{l}\text { Population } \\
\text { trend }\end{array}$ \\
\hline Burmeister's porpoise & Phocoena spinipinnis & Global & 2012 & DD & 2018 & NT & $A 3 d+4 d$ & Unknown \\
\hline Dall's porpoise & Phocoenoides dalli & Global & 2012 & LC & 2017 & LC & - & Unknown \\
\hline Harbor porpoise & Phocoena phocoena & $\begin{array}{l}\text { Global } \\
\text { Europe } \\
\text { Baltic Sea }\end{array}$ & $\begin{array}{c}2008 \\
- \\
1996\end{array}$ & $\begin{array}{l}\text { LC } \\
- \\
\mathbf{V u}\end{array}$ & $\begin{array}{l}2020 \\
2007 \\
2008\end{array}$ & $\begin{array}{l}\text { LC } \\
\text { VU } \\
\text { CR }\end{array}$ & $\begin{array}{l}- \\
\text { A2cde } \\
\text { C2a(ii) }\end{array}$ & $\begin{array}{l}\text { Unknown } \\
\text { Decreasing } \\
\text { Decreasing }\end{array}$ \\
\hline $\begin{array}{l}\text { Black sea harbor } \\
\text { porpoise }\end{array}$ & $\begin{array}{l}\text { Phocoena phocoena } \\
\text { ssp. relicta }\end{array}$ & Black sea & 1996 & VU & 2008 & EN & A1d+4cde & Decreasing \\
\hline $\begin{array}{l}\text { Indo-Pacific finless } \\
\text { porpoise }\end{array}$ & $\begin{array}{l}\text { Neophocaena } \\
\text { phocaenoides }\end{array}$ & Global & 2012 & VU & 2017 & Vu & $\mathrm{A} 2 \mathrm{cde}+3 \mathrm{cde}+4 \mathrm{cde}$ & Decreasing \\
\hline $\begin{array}{l}\text { Narrow-ridged finless } \\
\text { porpoise }\end{array}$ & $\begin{array}{l}\text { Neophocaena } \\
\text { asiaeorientalis }\end{array}$ & Global & 2012 & VU & 2017 & EN & A2bcde $+3 b c d e+4 b c d e$ & Decreasing \\
\hline $\begin{array}{l}\text { Yangtze finless } \\
\text { porpoise }\end{array}$ & $\begin{array}{l}\text { Neophocaena } \\
\text { asiaeorientalis ssp. } \\
\text { asiaeorientalis }\end{array}$ & $\begin{array}{l}\text { Global (Yangtze } \\
\text { River, China) }\end{array}$ & 1996 & EN & 2012 & CR & $A 3 b+4 b$ & Decreasing \\
\hline Spectacled porpoise & Phocoena dioptrica & Global & 2008 & DD & 2018 & LC & - & Unknown \\
\hline Vaquita & Phocoena sinus & Global & 2008 & CR & 2017 & CR & $\mathrm{A} 2 \mathrm{a}+4 \mathrm{~d} ; \mathrm{C} 1+2 \mathrm{a}$ (ii);D;E & Decreasing \\
\hline
\end{tabular}

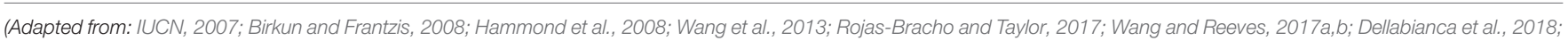
Félix et al., 2018; Jefferson and Braulik, 2018; Braulik et al., 2020).

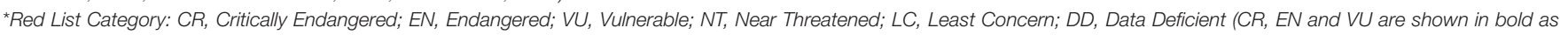
they are considered "threatened").

*^For a full explanation of Red List Criteria see IUCN (2012).

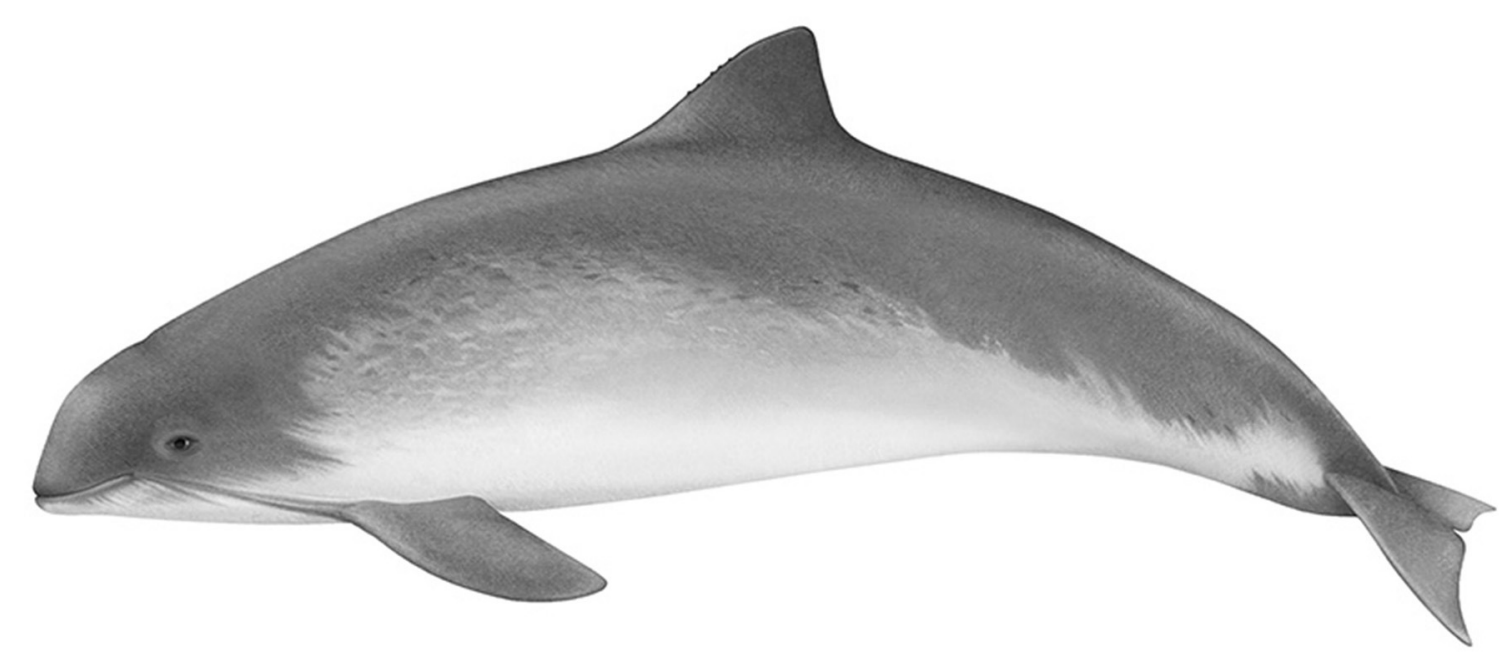

FIGURE 1 | Harbor porpoise (Image by Lucy Molleson).

\section{Northeast Atlantic}

In the 1970s, the harbor porpoise became scarce in the southernmost North Sea but has more recently returned. Various surveys have provided population estimates and the overall estimate from the latest (SCANS-III) was 466,569 (CV 0.15, 95\% CI: 345,000-630,000; Hammond et al., 2017). This survey also generated regional estimates: North Sea $(345,000)$, Kattegat/Belt Seas/Western Baltic Sea (42,300), Celtic and Irish Seas $(49,200)$, Atlantic Ireland and Scotland (29,000), and the Iberian Peninsula $(2,900)$. Evans (2020) compared surveys across the years and commented that comparison of abundance estimates for an equivalent area (North Sea) in 1994, 2005, and 2016 showed no significant trend and that this was also true for inner Danish waters.

Post-mortem examinations of 1,692 porpoises stranded in the United Kingdom between 1991 and 2010 showed that 23\% were thought to have died from infectious disease, $19 \%$ from attacks by bottlenose dolphins (Tursiops truncatus), 17\% were bycaught, $15 \%$ died from starvation and $4 \%$ stranded alive (Deaville and Jepson, 2011). In their review of threats to harbor porpoises in UK waters, IAMMWG et al. (2015) drew particular attention to bycatch in static net fisheries; acoustic disturbance through impulsive sound (e.g., pile driving, seismic surveys); and chemical pollution, notably persistent organic pollutants. 
TABLE 2 | Summary of conservation and monitoring commitments in the EU and United Kingdom [after IAMMWG et al. (2015)].

\begin{tabular}{|c|c|c|}
\hline Population characteristic & Ecological parameter & Links to legislation/Obligation \\
\hline Species distribution & Distribution range and pattern & $\begin{array}{l}\text { Habitats Directive and national implementing legislation, CMS and } \\
\text { ASCOBANS, ACCOBAMS, Wildlife and Countryside Act } 1981 \text { (WCA), } \\
\text { MSFD and national implementing legislation, Convention for the } \\
\text { Protection of the Marine Environment of the North-East Atlantic } \\
\text { (OSPAR) }\end{array}$ \\
\hline Population size & Population abundance & $\begin{array}{l}\text { Habitats Directive and national implementing legislation, CMS, and } \\
\text { ASCOBANS, ACCOBAMS, MSFD and national implementing } \\
\text { legislation, OSPAR, Regulation (EU) 2019/1241 }\end{array}$ \\
\hline \multirow[t]{2}{*}{ Population condition } & $\begin{array}{l}\text { Population demographic characteristics [e.g., body size, sex } \\
\text { ratio, reproductive rate, age class structure, genetic structure, } \\
\text { mortality (natural and anthropogenic)] }\end{array}$ & $\begin{array}{l}\text { Habitats Directive and national implementing legislation, WCA, } \\
\text { ASCOBANS, ACCOBAMS, OSPAR }\end{array}$ \\
\hline & $\begin{array}{l}\text { Population health (disease prevalence, pollutant } \\
\text { contamination) }\end{array}$ & ASCOBANS, ACCOBAMS, OSPAR, UK indicator proposed for MSFD \\
\hline Habitat for the species & $\begin{array}{l}\text { Size and quality (local scale protected areas as well as the } \\
\text { wider environment) }\end{array}$ & $\begin{array}{l}\text { Habitats Directive and national implementing legislation, WCA, MSFD } \\
\text { and national implementing legislation, Strategic Environmental } \\
\text { Assessment (2001/42/EC) Directive (SEA), Environmental Impact } \\
\text { Assessment Directive (EIA) }\end{array}$ \\
\hline
\end{tabular}

They noted other anthropogenic stressors but suggested that they were of less importance with low population impact. These included acoustic disturbance from continuous sounds [e.g., Acoustic Deterrent Devices (ADDs) and shipping]; collisions with renewable energy installations; and collisions with vessels. Other lethal interactions with gray seals (Halichoerus grypus) and orcas (Orcinus orca) were also noted. These authors also commented that climate change should be considered but that it was difficult to disentangle from short-term regional variability in prey resources.

There are marked seasonal and longer-term distribution shifts of porpoises in Europe, with distinct geographical seasonal peaks in sightings and strandings, and this may have significant implications for the management of anthropogenic impacts (IAMMWG et al., 2015). For example, large-scale surveys detected that, whilst the abundance of harbor porpoise in the North Sea and adjacent waters in July 2005 was similar to that recorded in July 1994, there was a distinct southerly shift between the two surveys (Hammond et al., 2013), as also reflected in strandings and sightings data.

Whilst the impacts of some factors remain difficult to scale, the primary threat in this region is clearly fisheries-related and in EU waters should be addressed by implementing regulations of the CFP and Habitats Directive to prevent bycatch.

\section{Iberian Peninsula}

The Iberian harbor porpoise population inhabits the coldwater upwelling zone along the Atlantic coasts of Spain and Portugal (Donovan and Bjørge, 1995; Sequeira, 1996; Fontaine et al., 2014; Fontaine, 2016; Hammond et al., 2017). This population may also extend into north-west Africa and is both morphologically (i.e., the animals are relatively large) and genetically distinct from other harbor porpoises. Fontaine et al. (2014) reported deep mtDNA divergence between the European North Atlantic, the Iberian/North-west African region and the Black Sea populations, indicating that the populations evolved independently for a considerable period. The Iberian population may even constitute a separate subspecies (NAMMCO and IMR, 2019). Population estimates based on abundance surveys, conducted in 2005 and 2016, suggest that the Iberian population is around 2,900 animals and the recorded population densities are among the lowest recorded on the European continental shelf (Hammond et al., 2013, 2017). Unpublished genetic evidence suggests a sharp decline in abundance over the last 30 years (IWC, 2020).

The International Whaling Commission (IWC) Scientific Committee reviewed the situation of the Iberian harbor porpoise in May 2020 and agreed that bycatch mortality is unsustainably high; that the introduction of Emergency Measures under the EU CFP would be justified; and that long-term solutions-which might include obligatory use of ADDs on fixed nets and trials of modified fishing practices in polyvalent and beach seine netsshould be developed (IWC, 2020). The Committee also called for effective monitoring of fishery bycatch in the region by Portugal and Spain that should include small-scale fisheries "with a particular emphasis on gillnet and beach seines gears."

Again, noting the importance of fishing in the region, the primary threat to the Iberian porpoise population has been identified as bycatch and, again, strict implementation of EU directives is crucial.

\section{Greenland}

There is evidence that porpoises from West Greenland are genetically distinct to those from other areas of the North Atlantic and that, possibly, these should be classified as a new subspecies (Andersen et al., 2001; Tolley et al., 2001; NAMMCO and IMR, 2019). The North Atlantic Marine Mammal Commission (NAMMCO) Harbor Porpoise Working Group recommends that genetically differentiated porpoises with site fidelity to West Greenland should be recognized as a subpopulation (NAMMCO, 2019) and considered as a separate management unit (NAMMCO, 2013). However, the Working 
Group also recommended that more research is needed to show that porpoises on the different coasts of Greenland belong to separate populations, as some animals tagged in West Greenland have been recorded in East Greenland (NAMMCO, 2019).

In 2019, the NAMMCO Harbor Porpoise Working Group calculated corrected abundance estimates using aerial survey data from 2007 and 2015 and satellite tracking of tagged porpoises (which gave the proportion of porpoises expected to have been outside the survey areas). The adjusted abundance estimate for 2007 for West Greenland was 69,595 porpoises $(\mathrm{CV}=0.37$; 95\% CI: 34,689-139,624) and for West and East Greenland combined it was 106,822 for 2015 (CV $=0.35$, 95\% CI: 55,149206,909) (Hansen and Heide-Jørgensen, 2013; Hansen et al., 2018; NAMMCO, 2019).

Harbor porpoises are hunted for their meat and blubber in Greenland, and the hunt tends to be opportunistic rather than organized, with hunters killing harbor porpoises when they come across them (Teilmann and Dietz, 1998; Nielsen and HeideJørgensen, 2013). Although abundance estimates are calculated, these do not seem to be used to determine quotas for the hunting of harbor porpoises and there are no limits for how many porpoises can be taken each year in Greenland (Nielsen and Heide-Jørgensen, $2013^{6}$ ). Hunters from Maniitsoq and the surrounding area in western Greenland are responsible for $40 \%$ of harbor porpoise catches (NAMMCO, 2019). Most animals are taken between May and November with a peak in July to October, reflecting the seasonal occurrence of harbor porpoises in Greenland's waters (Nielsen and Heide-Jørgensen, 2013). Fewer are caught in January to March, for example, because they move offshore during the winter and because the weather conditions are not favorable for hunting.

The current reporting system for harbor porpoise takes was implemented in 1993 (NAMMCO, 2019) and Table 3 shows that 58,309 harbor porpoises were reported killed in Greenland between 1993 and 2018, mainly in the West. The NAMMCO Harbor Porpoise Working Group has found that some catch numbers are under-reported or not reported at all to the official Piniarneq hunting database maintained by the Government of Greenland (NAMMCO, 2019) and it has been recommended that catch reports since 1993 should be corrected by a factor of 1.8 (NAMMCO, 2013).

Struck and lost harbor porpoises do not have to be reported in Greenland although some hunters do provide this information (NAMMCO, 2013). Until recently, Greenland did not record how many harbor porpoises were bycaught in its fisheries, though some data were recorded in fishery logbooks and by fisheries inspectors (NAMMCO, 2017). Before an online reporting system was introduced in 2013, bycatches of small cetaceans were reported as catches and would have been consumed or sold in the same way as hunted animals (NAMMCO, 2017). Since 2016, all vessels operating in Greenland waters must report marine mammal bycatch in their logbooks, the details of which are entered into the Ministry of Fisheries and Hunting's fisheries database (NAMMCO, 2017). There is still some concern over

\footnotetext{
${ }^{6}$ https://nammco.no/topics/hunting/

${ }^{7}$ https://nammco.no/topics/catch-database/
}

TABLE 3 | Harbor porpoise take in Greenland 1993-2018 (Adapted from NAMMCO catch database ${ }^{7}$ ).

\begin{tabular}{|c|c|c|c|}
\hline \multirow[t]{2}{*}{ Year } & \multicolumn{2}{|c|}{ Region } & \multirow[t]{2}{*}{ Total } \\
\hline & East & West & \\
\hline 1993 & 83 & 1,638 & 1,721 \\
\hline 1994 & 71 & 1,663 & 1,734 \\
\hline 1995 & N/A & 1,427 & 1,427 \\
\hline 1996 & N/A & 1,822 & 1,822 \\
\hline 1997 & 1 & 1,592 & 1,593 \\
\hline 1998 & N/A & 2,131 & 2,131 \\
\hline 1999 & N/A & 1,830 & 1,830 \\
\hline 2000 & N/A & 1,605 & 1,605 \\
\hline 2001 & 3 & 2,213 & 2,216 \\
\hline 2002 & 2 & 2,130 & 2,132 \\
\hline 2003 & 38 & 2,287 & 2,325 \\
\hline 2004 & 18 & 2,945 & 2,963 \\
\hline 2005 & 14 & 3,200 & 3,214 \\
\hline 2006 & 1 & 2,941 & 2,942 \\
\hline 2007 & 0 & 2,912 & 2,912 \\
\hline 2008 & 1 & 1,759 & 1,760 \\
\hline 2009 & 0 & 2,029 & 2,029 \\
\hline 2010 & 10 & 2,083 & 2,093 \\
\hline 2011 & 9 & 2,819 & 2,828 \\
\hline 2012 & 16 & 2,369 & 2,385 \\
\hline 2013 & 3 & 2,643 & 2,646 \\
\hline 2014 & 3 & 2,555 & 2,558 \\
\hline 2015 & 6 & 2,003 & 2,009 \\
\hline 2016 & 8 & 2,372 & 2,380 \\
\hline 2017 & 3 & 2,237 & 2,240 \\
\hline 2018 & & & 2,814 \\
\hline Total & & & 58,309 \\
\hline
\end{tabular}

the accuracy of reporting but the NAMMCO Bycatch Working Group has recommended ways in which data can be validated (NAMMCO, 2017).

Concerns for this region focus on the size and extent of a possibly distinct genetic population and the scale of deliberate takes. There is little information about bycatch and it is also possible that changing conditions related to climate change may be having an adverse effect. Action to mitigate known threats should be accompanied by increased research into the various threats facing harbor porpoises in this region as well as determining whether a separate subspecies is present.

\section{Baltic Sea}

The Baltic Sea is an inland sea in northern Europe with narrow straits connecting it through Kattegat and Skagerrak to the North Sea and the Northeast Atlantic. The limited influx of saline oceanic waters and the inflow of freshwater from rivers and precipitation means that its water is brackish. The Baltic Sea in its present form emerged at the end of the last ice age $\sim 10,000$ years ago, and the harbor porpoise, the only resident 
cetacean species in the Baltic, immigrated into the area $\sim 9,000$ years ago (Sommer et al., 2008). Consequently, the genetic and morphological differences (Galatius et al., 2012; Lah et al., 2016) seen between populations in the Baltic Sea Region today are the results of 9,000 years of separation, a comparably short time from an evolutionary perspective. Spatio-temporal distribution patterns also support the existence of a separate Baltic Proper population, showing spatial separation between populations during the breeding season (Sveegaard et al., 2015; Carlén et al., 2018; See Figure 2).

There are records of subfossil remains of harbor porpoises in the Gulf of Bothnia and Gulf of Finland from around 7,500 years ago (Forstén, 1975; Lõugas, 1999), and modern day records show presence of porpoises all the way up to the Bothnian Bay, although sightings so far north have become increasingly rare ${ }^{8}$. The historical population size in the Baltic Proper is not known but a questionnaire study involving fishermen, ferry operators, and coastguards along the Swedish coast shows a dramatic decline in sightings, from 1,638 sightings per observer year in the 1950s to 0.004 in the 1980s (Berggren and Arrhenius, 1995), a decrease of $99.8 \%$. Today the population is estimated at $\sim 500$ animals (SAMBAH, 2016).

There are very likely several reasons for this decline of the Baltic Proper harbor porpoise population. Harbor porpoises have no natural predators in the Baltic Sea, but were always hunted here. In prehistoric times they were part of the diet of the people along the Baltic Sea shores, and there are several findings of harbor porpoise remains in archaeological sites around the Baltic (Sommer et al., 2008). During the nineteenth century, harbor porpoises were mainly hunted for their blubber which was used to make oil. This continued during the world wars, but then ceased completely (Møhl-Hansen, 1954; Ropelewski, 1957).

During the first half of the twentieth century, there were several hard ice winters, with reports of harbor porpoises dying in large numbers in 1924, 1929, and 1940 (Johansen, 1929; Ropelewski, 1957; Otterlind, 1976). In the 1960s, two major anthropogenic threats emerged. Bioaccumulation of polychlorinated biphenyls (PCBs) was starting to result in noticeable problems, such as reduced reproduction in Baltic seals (Helle et al., 1976), and PCBs are now known to also cause reproductive failure in harbor porpoises (Murphy et al., 2015). These and other contaminants may also be one cause of respiratory tract lesions and the high parasite loads found in Baltic Proper harbor porpoises (Siebert et al., 2020). Additionally, thin nylon nets were introduced in the 1960s, and the salmon fisheries in the Baltic increased in intensity, very likely causing a significant increase in harbor porpoise bycatch (Otterlind, 1976). As an example, Lindroth (1962) was able to collect 50 bycaught harbor porpoises from the Baltic Proper salmon fisheries in just one year between 1960 and 1961, but only a decade later, in the 1970s, it took almost seven years to collect eight animals (Otterlind, 1976).

While the threats of environmental contaminants and bycatch have persisted since they were first observed, additional issues are likely further affecting population recovery. Firstly, the

${ }^{8} \mathrm{http}: / /$ maps.helcom.fi/website/mapservice/ ecosystem in the Baltic Sea is suffering from eutrophication and, alongside the loss of top predators such as seals, harbor porpoise and cod, this has led to an ecological regime shift (Österblom et al., 2007). As a result of the unhealthy ecosystem, the physiological condition of Baltic stocks of herring (Clupea harengus) and sprat (Sprattus sprattus) are deteriorating, which is having an influence on seal blubber thickness (Kauhala et al., 2017). It is probable that this decrease in prey quality could also negatively affect harbor porpoise nutrition and physiological condition. Secondly, the predicted increase in shipping in the Baltic (Larsson, 2016; HELCOM, 2018; Matczak et al., 2018), in combination with offshore construction projects, means increasing levels of underwater noise which can potentially cause disturbance and disruption of essential behaviors such as feeding (Wisniewska et al., 2016, 2018a,b), mating and nursing. Highfrequency vessel noise may also cause masking of the porpoises' own echolocation sounds. This could, for example, significantly decrease the distance of communication between a mother and her calf, or result in failure to detect a fishing net (Hermannsen et al., 2014). Together, all these threats mean extremely high pressure is being put on the Baltic Proper harbor porpoise, and female harbor porpoises in the German Baltic Sea often do not live long enough to reproduce even once (Kesselring et al., 2017, 2018; Siebert et al., 2020). It has recently been shown that the Baltic Proper population would be viable without anthropogenic stressors, but that even low levels of bycatch in combination with the rather low fecundity rate will almost certainly lead to population collapse (Cervin et al., 2020).

The severe threat of extinction to the harbor porpoise in the Baltic Proper has been known about for decades. In 1976, a paper was submitted to the International Council for the Exploration of the Sea (ICES) Marine Mammals Committee stating that the harbor porpoise was endangered in Swedish waters, especially in the Baltic Sea (Otterlind, 1976). In 1988, Skóra et al. (1988) noted that observations of harbor porpoises had decreased in Polish waters since the world wars. Various actions by international organizations have followed:

- In 1992, the harbor porpoise was listed in annexes II and IV of the EU Habitats Directive;

- In 1996, the Baltic Marine Environment Protection Commission or Helsinki Commission (HELCOM) adopted Recommendation $17 / 2$ on the Protection of harbor porpoise in the Baltic Sea Area ${ }^{9}$;

- In 2003 the ASCOBANS Recovery Plan for Baltic Harbor Porpoises, the Jastarnia plan, was adopted ${ }^{10}$;

- In 2008, the Baltic harbor porpoise was listed as Critically Endangered by the IUCN (Hammond et al., 2008); and

- For many years, the IWC Scientific Committee has repeatedly expressed serious concern for the population (IWC, 2020).

Within the range of the Baltic Proper harbor porpoise population, Natura 2000 sites were designated for the harbor porpoise in 2001-2002 by Poland, in 2004 and 2007 by Germany,

\footnotetext{
${ }^{9}$ https://www.helcom.fi/wp-content/uploads/2019/06/Rec-17-2.pdf

${ }^{10} \mathrm{https}$ ://www.ascobans.org/en/document/adoption-and-implementation-

jastarnia-and-north-sea-plans
} 


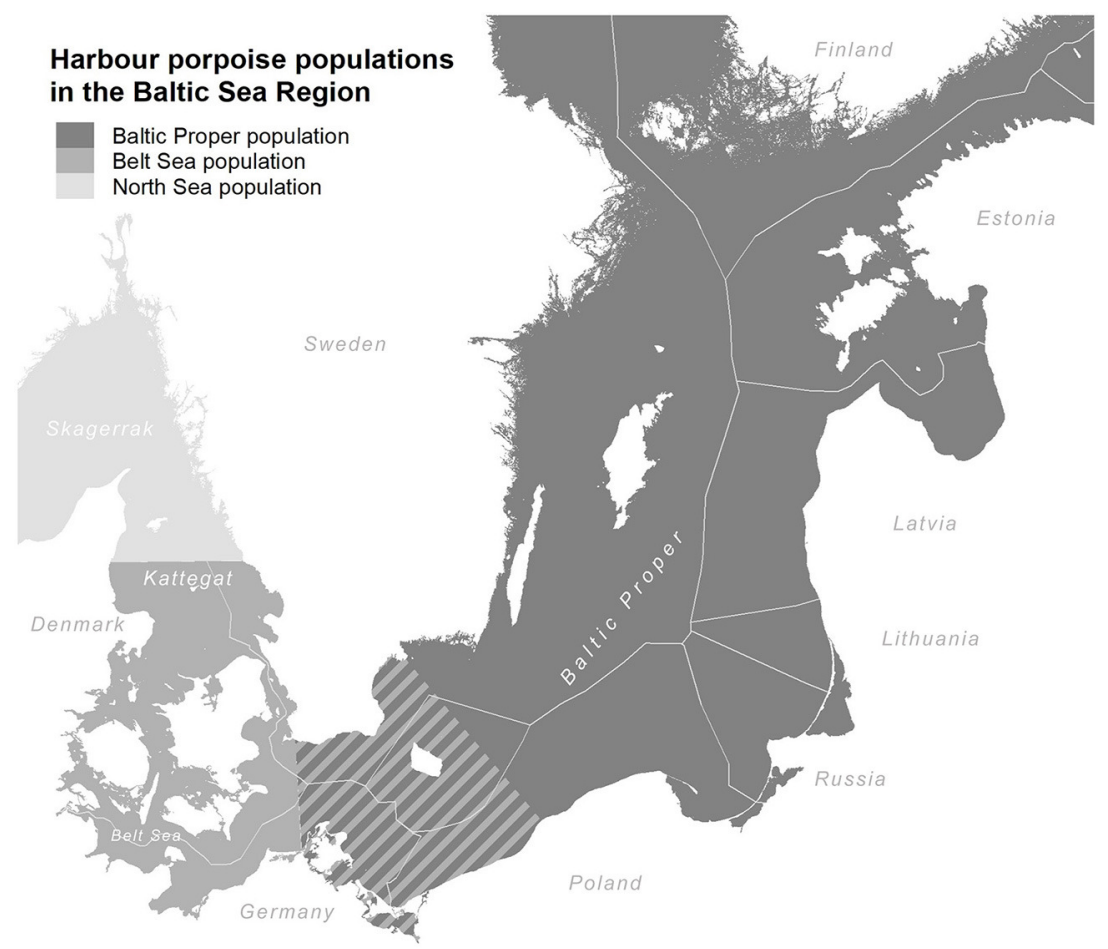

FIGURE 2 | Map showing the approximate distributions of harbor porpoise populations in the Baltic Sea Region (after Sveegaard et al., 2015; Carlén et al., 2018).

in 2009 by Denmark and in 2016 by Sweden. Numerous scientific papers have been published on the critical situation, calling for action (Otterlind, 1976; Berggren, 1994; Koschinski, 2001; Berggren et al., 2002), but no conservation measures or management plans have been applied, either within or outside these protected areas. Static net fisheries throughout the Baltic have continued to operate although there has been a reduction in fishing effort during the last decade due to various factors including a ban on cod (Gadus morhua) fisheries which was intended to protect the Eastern Baltic cod stocks, and was not related to the harbor porpoise population status.

Despite multiple studies showing a small but consistent separation, genetically, morphologically and spatially, between the Baltic Proper and the Belt Sea populations (see for e.g., Galatius et al., 2012; Lah et al., 2016; Carlén et al., 2018), there is still discussion about whether or not the Baltic Proper population can be considered separate. This has severely hindered conservation efforts, with countries essentially arguing that, if it is not a separate population, there is no need to ensure its survival. In fact, this argument was raised as recently as 2019, when the German Federal Ministry of Food and Agriculture effectively blocked the process to list the Baltic Proper harbor porpoise in Appendix I of $\mathrm{CMS}^{11}$. Two of the arguments used by the German Ministry largely mirror the arguments that have been used for decades, openly or covertly, to avoid taking conservation measures to protect this population: (1) the Baltic Proper harbor

\footnotetext{
${ }^{11}$ https://www.bmel.de/SharedDocs/Pressemitteilungen/DE/2019/072 schweinswale.html
}

porpoise is not a separate entity and is therefore not in danger of extinction, and (2) conservation measures to protect the Baltic Proper harbor porpoise would mean the end of traditional smallscale static net fisheries. A third argument has been that (3) widespread use of ADDs would ensonify a large proportion of the harbor porpoise habitat and would cause disturbance and behavioral reactions that could in turn have population-level effects. A fourth argument used by the German Federal Ministry of Food and Agriculture is that (4) the population size has increased in the North and Baltic Seas during the last decade.

We contend that:

(1) there are numerous scientific studies showing that the Baltic Proper harbor porpoise is in fact a separate population (see above). It is also highly unlikely that the Baltic Proper would be re-colonized by porpoises from the neighboring Belt Sea population, meaning that precautionary action should be taken;

(2) fisheries need to change as static nets are a serious threat to porpoises and many other species such as seals and seabirds in the Baltic, and we, therefore, need to find alternative gears and, in some cases, use ADDs to avoid bycatch. Indeed, ICES (2020) has deemed the use of ADDs necessary to protect the Baltic Proper harbor porpoise;

(3) harbor porpoises could be disturbed by the sound from ADDs and feeding, nursing and mating behaviors could be interrupted, however further study is necessary to understand this interaction. Furthermore, unless we are willing to completely close down static net fisheries, we will 
have to make the choice between disturbance from ADDs or lethal bycatch, until alternative mitigation methods and/or viable alternative fishing gear have been developed;

(4) there is no evidence of an increase in numbers of the Baltic Proper population, in fact there is only one estimate of the population size to date (SAMBAH, 2016) which points to critically low numbers. There is also no significant change in numbers in the Belt Sea or the North Sea (Evans, 2020).

One specific issue has been hindering the use of ADDs in the Baltic Sea, namely the fact that early versions of ADDs emitted sound at frequencies that were clearly audible to seals and other species attracting them to the fish in the nets (Bordino et al., 2002; Read et al., 2003; Carretta and Barlow, 2011; Snape et al., 2018). However, there are now models of ADDs on the market that emit sound at frequencies above seals' hearing range (Cornwall Wildlife Trust, 2013; Øien and Haug, 2017).

Another issue that has hindered effective conservation is the lack of data on bycatch. Under EU Council Regulation (EC) No. 812/2004, Member States were required to put in place monitoring and/or scientific studies to collect data on incidental catches from 1 January 2005, but the resulting data has been found sorely lacking (STECF, 2019). After the repeal of this regulation in 2019, collection of data on bycatch should take place under the Data Collection Framework (DCF) Regulation (2017/1004). However, concern has been raised that DCF observers focus on the catch that is taken on board, and therefore would miss many bycatch events which are usually detected during the hauling of nets. Under the Habitats Directive article 12.4, Member States are also requested to establish a system to monitor incidental capture and killing of species listed in Annex IV, which includes the harbor porpoise. However, few Member States have put in place such a system. Throughout the EU, the lack of data has been seen as a reason to not take action.

The failure of Germany to bring forward the proposal to list the Baltic Proper harbor porpoise in Appendix I of CMS means that the next chance to achieve this will likely be at the next CMS Conference of the Parties (COP), presently scheduled for 2023. In the meantime, a group of non-governmental organizations (NGOs) proposed a concerted action for the Baltic and Iberian harbor porpoise populations, which focuses on their own contributions whilst making the case for urgent action, and this was adopted at the CMS COP 13 in February 2020 (Anon, 2020).

After almost half a century of warnings, there is some movement at the European level to take active measures to protect the critically endangered Baltic Proper harbor porpoise. In July 2019, a group of NGOs submitted a proposal to the European Commission for emergency measures for this population, based on article 12 of the CFP (Regulation 1380/2013). This eventually lead to ICES publishing special request advice on "emergency measures to prevent bycatch of common dolphin (Delphinus delphis) and Baltic Proper harbor porpoise (Phocoena phocoena) in the Northeast Atlantic" in May 2020 (ICES, 2020). This advice lists recommended measures to prevent bycatch of the Baltic Proper harbor porpoise, which includes closures of static net (i.e., trammel net, gillnet and semi-driftnet) fisheries within Marine Protected Areas (MPAs) designated for the harbor porpoise and obligatory use of ADDs in all static net fisheries outside those MPAs, within the entire population distribution range. If all of these measures are implemented together, as described in the advice, it is expected that bycatch will reach a low enough level to allow the population to recover. However, it is still up to the countries around the Baltic Sea to ensure implementation through joint recommendations under the CFP (Regulation 1380/2013). For the Marine Baltic biogeographic region, decisions on such joint recommendations are taken in Baltfish (the regional fisheries body Baltic Sea Fisheries Forum), and the ICES advice and the resulting joint recommendations are currently (i.e. as of October 2020) being discussed. Several countries have already expressed their hesitance to implement the ICES advice in full, and the measures proposed in the first draft proposal from Baltfish do not go far enough to sufficiently reduce bycatch risk. Meanwhile, the European Commission is expecting Member States to act to fulfill their obligations under European environmental law. If insufficient measures are proposed by Baltfish, the Commission will likely implement emergency measures that are in line with the ICES advice. However, such emergency measures are only in effect for a maximum of 12 months.

The same group of NGOs also submitted a formal complaint to the European Commission in July 2019 concerning the noncompliance of 15 Member States with the Habitats Directive in failing to establish a system to monitor the incidental capture and killing of cetaceans, and for failing to take further measures to ensure that incidental capture and killing does not have a significant negative impact on the species concerned ${ }^{12}$. In July 2020, the Commission initiated an infringement procedure toward Sweden for non-compliance with Articles 6.2 and 12.4 of the Habitats Directive ${ }^{13}$. The Commission is also looking at other Member States for similar non-compliance issues. For Sweden, where $98 \%$ of the Baltic Proper porpoise population resides during the summer reproductive period, there now seem to be several incentives to take immediate and decisive action to protect this population, and we sincerely hope that other countries in the population range will also act swiftly and decisively.

In summary, the primary threat to this population is, again, fisheries-related but this is exacerbated by pollution impacts and unhelpful politics. Given the poor status of the population, urgent action must be taken on several fronts, including measures to mitigate bycatch as well as public engagement work to help the public and policy makers better understand this situation.

\footnotetext{
$12 \mathrm{https} / /$ ec.europa.eu/commission/presscorner/detail/en/INF_20_1212

${ }^{13}$ Article 6.2: Member States shall take appropriate steps to avoid, in the special areas of conservation, the deterioration of natural habitats and the habitats of species as well as disturbance of the species for which the areas have been designated, in so far as such disturbance could be significant in relation to the objectives of this Directive.

Article 12.4: Member States shall establish a system to monitor the incidental capture and killing of the animal species listed in Annex IV (a). In the light of the information gathered Member States shall take further research or conservation measures as required to ensure that incidental capture and killing does not have a significant negative impact on the species concerned.
} 


\section{Black Sea and Sea of Azov}

The Black Sea, like the Baltic Sea, is another inland sea. It is situated between south-eastern Europe and Asia Minor (Birkun, 2002a). At the north-eastern corner it is connected to the Sea of Azov and in the southwest to the Sea of Marmara and the Mediterranean (Rohling et al., 2009). Black Sea harbor porpoises (P.p. relicta) are found mainly in the coastal waters of the Black Sea and, seasonally, they are also found in the Seas of Azov and Marmara (Vishnyakova and Gol'din, 2015). The Kerch Strait (Russia/Ukraine), Cape Sarych to Cape Khersones (Ukraine) and Cape Anaklia to Sarp (Georgia) have all been recognized by ACCOBAMS as Areas of special importance for Black Sea harbor porpoises ${ }^{14}$.

The species entered the Black Sea between 5,000 and 8,000 ago after the Black Sea was reconnected to the Mediterranean $\sim 8,000$ ago (Rohling et al., 2009; Fontaine, 2016), and has been separated from the eastern Atlantic populations of harbor porpoises for thousands of years (Viaud-Martínez et al., 2007; Fontaine et al., 2012). They share no haplotypes and are morphologically different with smaller bodies and skulls, wider and longer rostrums, and other physical differences. Within the subspecies, P.p. relicta it has been suggested that there may be differentiated subpopulations with different stocks in the northwest, north-east (Crimean and Caucasian), south-east and southwest areas of the Black Sea (Mikhalev, 2005) and the Sea of Azov (Gol'din, 2004). Porpoises from the Sea of Azov are slightly larger than those from the Black Sea and have distinct skull morphology (Gol'din and Vishnyakova, 2015). Sexual dimorphism is also pronounced in the Sea of Azov, with females being significantly larger than males (Gol'din and Vishnyakova, 2015). However, genetic analysis has, so far, shown a nearly complete genetic homogeneity across the subspecies' range and, therefore, the morphological differences may be due to other processes (Ben Chehida et al., 2020).

In 2008, the Black Sea harbor porpoise population was estimated to be, at the most, in the low tens of thousands (Birkun and Frantzis, 2008), which is thought to be $70-90 \%$ lower than historical numbers (Birkun and Frantzis, 2008; Fontaine et al., 2012). This drastic decline is attributed to (1) extensive directed hunting that killed tens of thousands of porpoises every year and took place from the 1830s until it was first banned in Romania, Bulgaria and the former Soviet republics in 1966, and then in Turkey in 1983, with some illegal hunting taking place until 1991 (Berkes, 1977; IWC, 2004; Birkun and Frantzis, 2008); and (2) incidental bycatch in, mainly, bottom-set gillnets for turbot (Scophthalmus maeoticus). This is currently the main cause of harbor porpoise mortality in the Black Sea, killing thousands of animals each year (Birkun and Frantzis, 2008; ACCOBAMS, 2020a).

Additionally, harbor porpoises in the Black Sea face an accumulation of anthropogenic threats (Birkun, 2002a), which are similar to those facing the Baltic Proper harbor porpoise. Pollution from shipping, industrial and mining wastes, nutrients from agriculture, sewage, and other sources is a significant issue in the Black Sea (Birkun, 2002a). Harbor porpoises there

\footnotetext{
${ }^{14} \mathrm{https} / /$ accobams.org/conservations-action/protected-areas/
}

are contaminated by heavy metals and organochlorine residues, including dichlorodiphenyltrichloroethane (DDT) and PCBs (Tanabe et al., 1997; Evtimova et al., 2019). The Black Sea has also undergone ecosystem changes very similar to those of the Baltic Sea, with eutrophication, overfishing, and removal of top predators leading to regime shifts in the relatively species-poor ecosystem (Oguz and Gilbert, 2007).

Porpoises have also been subject to mass mortalities, for example during unusual events such as when the Sea of Azov freezes and porpoises get trapped in the ice, unable to reach the Black Sea through the Kerch Strait (Birkun, 2002b) There were also mass deaths due to parasitic and bacterial infections in 1989 and 1990 (Birkun and Frantzis, 2008). Sometimes the reason for an unusual mass mortality of cetaceans cannot be determined, for example the reason for 114 cetaceans (at least 53 of which were harbor porpoises) stranding in the Turkish Western Black Sea in 2009 (Tonay et al., 2012b).

Today, activities related to oil and gas extraction in the Black Sea region are undertaken without the necessary monitoring of cetaceans (ACCOBAMS, 2020a). Construction work in the Kerch Strait, which is one of the areas recognized by ACCOBAMS as an Area of special importance for Black Sea cetaceans, including the harbor porpoise, is carried out without mitigation measures to limit the effects of underwater noise.

Studies looking at using ADDs to mitigate bycatch of harbor porpoises have been carried out in recent years, however, the results are somewhat contradictory. In a study using $10 \mathrm{kHz}$ ADDs in the turbot fishery in Bulgarian waters bycatch was significantly reduced (Zaharieva et al., 2019), while another study showed that ADDs did not have the intended effect (Gol'din et al., 2020).

The isolation of the Black Sea porpoises makes them especially vulnerable, as does the degraded nature of their environment. Again, bycatch is the most prominent and urgent threat and gillnets the most obvious problem. EU directives are only valid in part of the Black Sea, so international collaboration including other ranges states and testing and implementation of bycatch mitigation methods, such as ADDs and alternative gear, should be the highest priority.

\section{Mediterranean}

Records of harbor porpoises in the Mediterranean are rare (Rosel et al., 2003). A small number of cases of live or stranded porpoises have been reported in the northern Aegean (Frantzis et al., 2001) and Turkish or southern Aegean Sea (Güçlüsoy, 2008; Tonay and Dede, 2013). These animals are P.p. relicta and likely to have entered the Aegean from the Black or Marmara Sea through the Strait of Çanakkale, although there is also the possibility that they belong to a local, isolated geographically discrete population (Frantzis et al., 2001). Some genetic studies have hinted at the possibility of an isolated harbor porpoise population in the Marmara Sea (Viaud-Martínez et al., 2007; Tonay et al., 2012a), however, Ben Chehida et al. (2020) found genetic homogeneity across samples from the Aegean, Marmara, Black and Azov Seas. Further research in the area is clearly needed to confirm this and, if there is a distinct population, it is clearly small and vulnerable. 


\section{CONSERVATION STATUS OF OTHER PORPOISE SPECIES}

As already noted for the harbor porpoise, although a species may have one status regarding its risk of extinction on a global scale, subpopulations and subspecies often need to be assessed separately and may fall into a different category. The Dall's porpoise (Phocoenoides dalli), for example, has only been assessed globally (LC) but the assessors noted that subspecies P.d. truei only inhabits the western North Pacific (Jefferson and Braulik, 2018) and, as it constitutes a single population (IWC, 2002), it deserves a separate assessment.

The spectacled porpoise (Phocoena dioptrica) was also listed as LC in its most recent assessment in 2018 but the assessors noted that it could easily have been listed as DD again (as it was in 2008) because information about it is sparse and there are no abundance estimates (Dellabianca et al., 2018). In fact, the assessors also considered listing it as NT before opting for LC, whilst noting that this status should be considered as provisional pending further information. The NT status for Burmeister's porpoise (Phocoena spinipinnis) is also considered provisional and the species may require the status of VU (Félix et al., 2018). The Peruvian population of Burmeister's porpoise may require a higher risk category than other populations and could, in fact, require its own taxon. Likewise, the assessors of the Narrow-ridged finless porpoise (Neophocaena asiaeorientalis) recommend that at least two sub-populations should be assessed separately (Wang and Reeves, 2017a).

Other porpoise species face similar threats to those encountered by the harbor porpoise in Europe. Some have been hunted e.g., Burmeister's porpoise in the Peruvian Pacific (Félix et al., 2018; Van Waerebeek et al., 2018) and Dall's porpoises in Japan (Jefferson and Braulik, 2018). Bycatch is also an all-pervading issue for many other porpoise species e.g., Burmeister's porpoise, Dall's porpoise, Indo-Pacific finless porpoise, Narrow-ridged finless porpoise, Yangtzee finless porpoises and the vaquita (Wang et al., 2013; Wang and Reeves, 2017a; Félix et al., 2018; Jefferson and Braulik, 2018; Brownell et al., 2019). The need for better international cooperation to address threats is highlighted in all cases and especially for the vaquita (Phocoena sinus), where bycatch (much of it in illegal gillnets) has driven the species to the brink of extinction with an estimated population of only 19 individuals remaining (Jaramillo-Legorreta et al., 2019). See section Vaquita below.

\section{Vaquita}

According to the Cetacean Specialist Group of the IUCN, the vaquita, Phocoena sinus, is currently the most endangered cetacean worldwide, with a highly restricted range in the upper Gulf of California in Mexico, mainly in a small area near the town of San Felipe ${ }^{15}$. In 1990, the vaquita was moved from VU to EN (Rojas-Bracho and Taylor, 2017). In 1996, it became critically endangered (CR). It was not assessed again for the Red List until 2007 (when it was still considered CR) and then again in 2017 (also CR).

\footnotetext{
${ }^{15}$ https://iucn-csg.org/vaquita/
}

The most serious threat to the vaquita's survival has long been known to be mortality in gillnets of various mesh sizes (Rojas-Bracho and Taylor, 2017). The International Committee for the Recovery of the Vaquita (CIRVA), established in 1997, has consistently called for a permanent ban on all gillnets throughout the range of the vaquita, and also on gillnet manufacture and possession. In 2017, the transport and use of gillnets was made illegal but with exemptions for two fish species (the Pacific sierra, Scomberomorus sierra and the Gulf corvina, Cynoscion othonopterus). Night fishing was also banned and launch and landing points were restricted. However, illegal fishing has continued, a situation exacerbated by the illegal fishery for the critically endangered totoaba, Totoaba macdonaldi, a large fish species whose swim bladder fetches very high prices in the Asian market (Alvarado Martínez and Martínez, 2018). Both the vaquita and the totoaba are on Appendix I of the Convention on International Trade in Endangered Species of Wild Fauna and Flora (CITES), meaning that international trade in them is meant to be banned.

The vaquita has been little studied but in many respects appears to be similar to the much better-studied harbor porpoise (Rojas-Bracho et al., 2006). Longevity for both species is 20 years + and both become sexually mature between about 3 and 6 years old. A significant difference between the two species is that the vaquita may not breed annually, unlike some populations of the harbor porpoise, although this has recently been questioned (Taylor et al., 2019).

Following a CIRVA recommendation, an attempt was made in 2017 to capture some vaquitas and take them into a protective sanctuary (Pennisi, 2017). This attempt failed and is unlikely to be repeated.

In 2020, at its most recent meeting, the Scientific Committee of the IWC received news of vaquita sightings made during surveys in 2019 (IWC, 2020). While individuals were recorded, sightings were too few to support mark-recapture estimation of population size and expert elicitation suggests a population now of only 4-17 individuals. It was also reported that there was continued "rampant illegal gillnet fishing" in the vaquita's range (including within the "Zero Tolerance Area" designated to protect the species). More positively, it was estimated that there were 3 calves. The fact that this greatly diminished population is still breeding gives some hope for its survival.

Nonetheless, the population is very small, and the IWC Scientific Committee reiterated its grave concern about the vaquita's plight and the urgent need to remove gillnets from the species' range (IWC, 2020). It also repeated its previous recommendation "that the Government of Mexico fully mobilize its enforcement assets to eliminate illegal fishing in at least the Zero Tolerance Area where the goal must be to remove any illegal net within hours of its deployment." The Scientific Committee also made some very specific recommendations for the Mexican government, including the need for 24-h surveillance and monitoring to address illegal fishing.

One primary lesson from the vaquita's situation may be that once a taxon has declined to a certain level, recovery is highly problematic, if not impossible. Hence, action needs to come at a much earlier stage. The assignment of a status of "critically 
endangered" should not be seen as the "starting gun" for urgent action. It needs to come earlier when there are warning signs, such as high bycatch.

\section{DISCUSSION AND CONCLUSION}

Bycatch in fisheries is the main and most immediate threat to European harbor porpoise populations, including the critically endangered Baltic Proper and the newly-recognized Iberian populations. In practice, mitigation could be carried out through the closing of high-risk fisheries in important areas of harbor porpoise distribution, and through the use of alternative gear, gear adaptations or ADDs. All of these measures cost time and money and action would also need to be enforced. In the EU this should be through the implementation of existing legislation such as the CFP and Habitats Directive, as well as the effective monitoring of bycatch and fishing effort. Other threats such as environmental contaminants and disturbance also need to be tackled, and, in some cases, further research and public education campaigns are essential.

Indeed, the time has long been ripe to take decisive action. Over 30 years ago, the worrying conservation status of many small cetaceans was highlighted by Brownell et al. (1989) in their article "The plight of the 'forgotten' whales." They pointed out that although many populations of "great whales" were either stable or on the road to recovery thanks to international bans on whaling and other protective measures, many small cetaceans were on a downhill trajectory. Little was known about the vaquita at that time, but they knew that it should be considered "endangered." Unfortunately, it seems that porpoises are still very much "out of sight, out of mind" for many governments, policy makers and the general public. Recently, over 350 cetacean scientists signed a public statement highlighting their concern about the status of cetacean populations worldwide and calling for precautionary action from the international community ${ }^{16}$. In the list of endangered species accompanying the statement they specifically mention four porpoise species (including the Baltic Proper subpopulation of the harbor porpoise) and two subspecies.

We have long known that as a population becomes smaller it becomes increasingly difficult to measure its trajectory (Taylor and Gerrodette, 1993) and, consequently, detection of a decline should not be a criterion for action for a rare species. Without wishing to be defeatist, we fear it may be too late to save the vaquita. Its lasting legacy could be that we learn from its demise and tackle bycatch urgently in other porpoise populations.

In Europe, fisheries are of significant economic and political concern, so addressing bycatch is particularly difficult. Whilst there are some promising results from ADDs, any changes to fisheries practices will entail economic costs. Is society willing to pay such costs to protect a species that many people still fail to recognize and yet is no less a part of European fauna than a brown bear (Ursos arctos) or a gray wolf (Canis lupus)? Perhaps the response in Germany to the proposal that the Baltic Proper harbor porpoise should be listed on Appendix I of CMS provides an important lesson, seemingly showing that immediate economic concerns are judged more important, despite many years of formally discussing the status and conservation needs of the Baltic Proper harbor porpoise, notably at ASCOBANS, which has a dedicated conservation action plan for it. It appears that German ministries may have disagreed and instead of taking a precautionary position, the Federal Ministry of Food and Agriculture decided that this population did not require protection, both because the entire species is not considered endangered and because of the problems that action would present to the relevant fisheries. The logical conclusion of this position is that it is acceptable to allow population units to become regionally extinct. Would the same argument be made in favor of a distinct population of a well-known terrestrial species, such as a giraffe (Giraffa camelopardalis)? We think not and we would like to see porpoises being offered the appropriate level of protection.

Bycatch is clearly not the only issue for these species. The threat from PCBs, may be significant at even lower levels than previously thought (Williams et al., 2020) and other novel compounds also accumulate in porpoise bodies and are passed to their young, for example phthalate metabolites (Rian et al., 2020). Additionally, "disturbance," including acoustic disturbance, has been identified as a problem, especially because of the high metabolic requirement of a small animal living in a cold environment to feed at a high and almost continuous rate (IAMMWG et al., 2015; Wisniewska et al., 2016; Evans, 2020).

More positively, the EU is now starting to act to address the threats to cetaceans in Europe and some new international initiatives to develop and provide appropriate mitigation advice are in progress. Arguably, foremost among these is IWC's bycatch mitigation initiative. The IUCN's primary role to date has been to identify the statuses of cetacean species but it, too, is now moving to try to assist directly in conservation action, establishing a new group to work on what they are calling "integrated conservation planning for cetaceans"17.

We agree with others that conservation must be multifaceted, adaptable, and tailored to local conditions (e.g., IAMMWG et al., 2015). Our main conclusion is that porpoises in general should be regarded as exceptionally vulnerable. They live on an energetic knife-edge; they have a relatively low reproductive rate and a propensity to accumulate certain pollutants and they are subject to fisheries bycatch and the escalation of other harmful human activities in their particular habitats. Comparing the critically endangered vaquita with a widespread species, such as the harbor porpoise, re-emphasizes the vulnerability of small distinct population units. The legislation in Europe appears relevant but what seems to be lacking is compliance by Member States in the form of appropriate implementation and follow-up. We believe that a speedier and much more precautionary response to what may be judged as unsustainable removals needs to be made, accompanied by more action on chemical pollution and disturbance. A further challenge that needs to be addressed is an educational one focused on introducing the harbor porpoise to the many people in Europe who do not know it exists or cannot identify it (Nunny et al., 2020), let alone recognize the need to conserve it.

\footnotetext{
${ }^{16}$ https://www.mammalresearchinstitute.science/whale- unit
}

$\overline{{ }^{17} \text { https://iucn-csg.org/integrated-conservation-planning-for-cetaceans-icpc/ }}$ 


\section{AUTHOR CONTRIBUTIONS}

MS thought of the theme of the paper. All authors researched and wrote it equally.

\section{FUNDING}

MS and LN were supported by Humane Society International during the writing of the paper and IC by Coalition Clean Baltic.

\section{REFERENCES}

ACCOBAMS (2020a). "Report on the conservation status of cetaceans and relevant activities in Black Sea," in Thirteenth Meeting of the ACCOBAMS Scientific Committee, Monaco 26-28 February 2020 (ACCOBAMS). Available online at: https://accobams.org/wp-content/uploads/2020/01/Final_Report_ ACCOBAMS_SC13.pdf

ACCOBAMS (2020b). "Assessment of the conservation status of cetaceans in the ACCOBAMS area," in Thirteenth Meeting of the ACCOBAMS Scientific Committee, Monaco 26-28 February 2020. Available online at: https:// accobams.org/wp-content/uploads/2020/02/SC13.Doc10_Rev1_Assessmentof-Conservation-status- of-cetaceans-in-the-ACCOBAMS-Area.pdf

Alvarado Martínez, I., and Martínez, E. R. (2018). "Trafficking of totoaba maw," in Green Crime in Mexico: A Collection of Case Studies, eds I. Arroyo-Quiroz and T. Wyatt (Cham: Palgrave Macmillan), 149-170. doi: 10.1007/978-3-319-75286-0_12

Andersen, L. W., Ruzzante, D. E., Walton, M., Berggren, P., Bjørge, A., and Lockyer, C. (2001). Conservation genetics of harbour porpoises, Phocoena phocoena, in eastern and central North Atlantic. Conserv. Genet. 2, 309-324. doi: 10.1023/A:1012534212853

Anon (2020). Proposal for a Concerted Action for the Harbour Porpoise (Phocoena phocoena) Made by Coalition Clean Baltic, Whale and Dolphin Conservation, Humane Society International and ORCA. Available online at: https:// www.cms.int/sites/default/files/document/cms_cop13_doc.28.2.7_rev.1_caharbour-porpoise_e_0.pdf

Ben Chehida, Y., Thumloup, J., Vishnyakova, K., Gol'din, P., and Fontaine, M. C. (2020). Genetic homogeneity in the face of morphological heterogeneity in the harbor porpoise from the Black Sea and adjacent waters (Phocoena phocoena relicta). Heredity 124, 469-484. doi: 10.1038/s41437-019-0284-1

Berggren, P. (1994). Bycatches of the harbour porpoise (Phocoena phocoena) in the Swedish Skagerrak, Kattegat and Baltic Seas; 1973-1993. Rep. Int. Whal. Commn. 15, 211-215.

Berggren, P., and Arrhenius, F. (1995). Sightings of harbor porpoises (Phocoena phocoena) in Swedish waters before 1990. Rep. Int. Whal. Comm. 16, 99-107.

Berggren, P., Wade, P. R., Carlström, J., and Read, A. J. (2002). Potential limits to anthropogenic mortality for harbour porpoises in the Baltic region. Biol. Conserv. 103, 313-322. doi: 10.1016/S0006-3207(01)00142-2

Berkes, F. (1977). Turkish dolphin fisheries. Oryx 14, 163-167. doi: 10.1017/S0030605300015222

Birkun, A. A. Jr., and Frantzis, A. (2008). Phocoena phocoena ssp. relicta. The IUCN Red List of Threatened Species 2008: e.T17030A6737111. doi: 10.2305/IUCN.UK.2008.RLTS.T17030A6737111.en

Birkun, A. Jr. (2002a). "Cetacean habitat loss and degradation in the black sea," in Cetaceans of the Mediterranean and Black Seas: State of Knowledge and Conservation Strategies. A Report to the ACCOBAMS Secretariat, Section. 8, ed G. Notarbartolo di Sciara (ACCOBAMS), 12.

Birkun, A. Jr. (2002b). "Natural mortality factors affecting cetaceans in the black sea," in Cetaceans of the Mediterranean and Black Seas: State of Knowledge and Conservation Strategies. A Report to the ACCOBAMS Secretariat, Section. 16, ed G. Notarbartolo di Sciara (ACCOBAMS), 13.

Bjørge, A., and Donovan, G. P (eds.). (1995). Biology of the Phocoenids. Special Issue 16. Cambridge: International Whaling Commission, 189-197.

Bordino, P., Kraus, S., Albareda, D., Fazio, A., Palmerio, A., Mendez, M., et al. (2002). Reducing Incidental mortality of franciscana dolphin Pontoporia blainvillei with acoustic warning devices attached to fishing nets. Mar. Mammal Sci. 18, 833-842. doi: 10.1111/j.1748-7692.2002.tb01076.x

\section{ACKNOWLEDGMENTS}

This paper has been informed by the work of and discussions with many colleagues, including Peter Evans, who work on cetacean conservation in Europe and beyond. The opinions expressed here are our own and not necessarily those of any institutions or organizations with which we are or have been associated.

Braulik, G., Minton, G., Amano, M., and Bjørge, A. (2020). Phocoena phocoena. The IUCN Red List of Threatened Species 2020: e.T17027A50369903.

Brownell, R. L., Jr., Ralls, K., and Perrin, W. F. (1989). The plight of the 'forgotten whales'. Oceanus 32, 5-11.

Brownell, R. L. Jr., Reeves, R. R., Read, A. J., Smith, B. D., Thomas, P.O. (2019). Bycatch in gillnet fisheries threatens critically endangered small cetaceans and other aquatic megafauna. Endang. Species. Res. 40, 285-296. doi: 10.3354/esr00994

Carlén, I., Thomas, L., Carlström, J., Amundin, M., Teilmann, J., Tregenza, N., et al. (2018). Basin-scale distribution of harbour porpoises in the Baltic sea provides basis for effective conservation actions. Biol. Conserv. 226, 42-53. doi: 10.1016/j.biocon.2018.06.031

Carretta, J. V., and Barlow, J. (2011). Long-term effectiveness, failure rates, and dinner bell properties of acoustic pingers in a gillnet fishery. Mar. Technol. Soc. J. 45, 7-19. doi: 10.4031/MTSJ.45.5.3

Cervin, L., Harkonen, T., and Harding, K. C. (2020). Multiple stressors and data deficient populations; a comparative life-history approach sheds new light on the extinction risk of the highly vulnerable Baltic harbour porpoises (Phocoena phocoena). Environ. Int. 144:106076. doi: 10.1016/j.envint.2020.106076

Cornwall Wildlife Trust, Cornwall Seal Group, and Cornish Seal Sanctuary. (2013). Investigation into the Attraction of Atlantic Grey Seals (Halichoerus grypus) to the Fishtek Banana Pinger. Cornwall Wildlife Trust

Deaville, R. and Jepson, P. D. (2011). UK Cetacean Strandings Investigation Programme Final Report for the Period 1st January 2005-31st December 2010. Available online at: http://randd.defra.gov.uk/Document.aspx?Document= FinalCSIPReport2005-2010_finalversion061211released[1].pdf

Dellabianca, N., Pitman, R. L., and Braulik, G. (2018). Phocoena Dioptrica. The IUCN Red List of Threatened Species 2018: e.T41715A50381544. doi: 10.2305/IUCN.UK.2018-2.RLTS.T41715A50381544.en

Donovan, G. P., and Bjørge, A. (1995). "Harbour porpoises in the North Atlantic," in Reports of the International Whaling Commission, Special Issue 16, eds A. Bjørge and G. P. Donovan (Cambridge: International Whaling Commission), 3-25.

Evans, P. G. H. (2020). European Whales, Dolphins and Porpoises: Marine Mammal Conservation in Practice. London: Academic Press.

Evtimova, V., Parvanov, D., Grozdanov, A., Tserkova, F., Zlatkov, B., Vergilov, V., et al. (2019). Heavy metals in bones from harbour porpoises Phocoena phocoena from the Western Black Sea Coast. ZooNotes 136, 1-4. Available online at: http://www.zoonotes.bio.uni-plovdiv.bg/ZooNotes_2019/ZooNotes_2019_ Full.pdf

Félix, F., Alfaro, J., Reyes, J., Mangel, J., Dellabianca, N., Heinrich, S., et al. (2018). Phocoena Spinipinnis. The IUCN Red List of Threatened Species 2018: e.T17029A50370481. doi: 10.2305/IUCN.UK.2018-2.RLTS.T17029A50370481.en

Fontaine, M. (2016). "Harbour porpoises, Phocoena phocoena in the Mediterranean sea and adjacent regions: biogeographic relicts of the last glacial period. Adv. Mar. Biol. 75, 333-358. doi: 10.1016/bs.amb.2016. 08.006

Fontaine, M. C., Roland, K., Calves, I., Austerlitz, F., Palstra, F. P., Tolley, K. A., et al. (2014). Postglacial climate changes and rise of three ecotypes of harbour porpoises, Phocoena phocoena, in western Palearctic waters. Mol. Ecol. 23, 3306-3321. doi: 10.1111/mec.12817

Fontaine, M. C., Snirc, A., Frantzis, A., Koutrakis, E., Ozturk, B., Ozturk, A. A., et al. (2012). History of expansion and anthropogenic collapse in a top marine predator of the Black sea estimated from genetic data. Proc. Natl. Acad. Sci. U.S.A. 109, E2569-E2576. doi: 10.1073/pnas.1201258109 
Forstén, A. (1975). Subfossil harbour porpoises (Mammalia, Cetacea) in Finland. Memo. Soc. Fauna Flora Fenn. 29-31.

Frantzis, A., Gordon, J., Hassidis, G., and Komnenou, A. (2001) The enigma of harbour porpoise presence in the Mediterranean sea. Mar. Mamm. Sci. 17(4), 937-944. doi: 10.1111/j.1748-7692.2001.tb01307.x

Galatius, A., Kinze, C. C., and Teilmann, J. (2012). Population structure of harbour porpoises in the Baltic region: evidence of separation based on geometric morphometric comparisons. J. Mar. Biol. Assoc. 92, 1669-1676. doi: $10.1017 / S 0025315412000513$

Gol'din, P., Popov, D., Vishnyakova, K., Meshkova, G., Düzgünes, E., Panayotova, M., et al. (2020). "Pilot studies on cetacean bycatch monitoring and bycatch mitigation measures in the Black Sea," in Thirteenth Meeting of the ACCOBAMS Scientific Committee, Monaco 26-28 February 2020. Available online at: https://accobams.org/wp-content/uploads/2020/01/SC13. Inf07_Pilot-studies-on-cetacean-bycatch-monitoring-BS.pdf

Gol'din, P. E. (2004). Growth and body size of the harbour porpoise, Phocoena phocoena (cetacean, phocoenidae), in the sea of Azov and the Black sea. Vestnik Zool. 38, 59-73. Available online at: http://dspace.nbuv.gov.ua/handle/ $123456789 / 3286$

Gol'din, P. E., and Vishnyakova, K. A. (2015). Differences in skull size of harbour porpoises, Phocoena phocoena (cetacean), in the sea of Azov and the Black sea: evidence for different morphotypes and populations. Vestnik Zool. 49, 171-180. doi: 10.1515/vzoo-2015-0017

Güçlüsoy, H. (2008). The First Confirmed Report of the Harbour Porpoise (Phocoena phocoena) in the Turkish Aegean Sea. JMBA2-Biodiversity Records. Available online at: http://citeseerx.ist.psu.edu/viewdoc/download?doi=10.1.1. 594.5964\&rep=rep $1 \&$ type $=$ pdf

Hammond, P. S., Bearzi, G., Bjørge, A., Forney, K. A., Karczmarski, L., Kasuya, T., et al. (2008) Phocoena phocoena (Baltic Sea subpopulation)(Errata Version Published in 2016). The IUCN Red List of Threatened Species 2008: e.T17031A98831650. doi: 10.2305/IUCN.UK.2008.RLTS.T17031A6739565.en

Hammond, P. S., Lacey, C., Gilles, A., Viquerat, S., Börjesson, P., Herr, H., et al. (2017). Estimates of Cetacean Abundance in European Atlantic Waters in Summer 2016 From the SCANS-III Aerial and Shipboard Surveys. Available online at: https://synergy.st-andrews.ac.uk/scans3/files/2017/05/SCANS-IIIdesign-based-estimates-2017-05-12-final-revised.pdf

Hammond, P. S., Macleod, K., Berggren, P., Borchers, D. L., Burt, M. L., Cañadas, A., et al. (2013). Cetacean abundance and distribution in European Atlantic shelf waters to inform conservation and management. Biol. Conserv. 164, 107-122. doi: 10.1016/j.biocon.2013.04.010

Hansen, R. G., Boye, T. K., Larsen, R. S., Nielsen, N. H., Tervo, O., Nielsen, R. D., et al. (2018). Abundance of whales in West and East Greenland in Summer 2015. NAMMCO Sic. Public 11, 17. doi: 10.1101/391680

Hansen, R. G., and Heide-Jørgensen, M. P. (2013). Spatial trends in abundance of long-finned pilot whales, white-beaked dolphins and harbour porpoises in West Greenland. Mar. Biol. 160, 2929-2941. doi: 10.1007/s00227-0132283-8

HELCOM (2018). HELCOM Assessment on Maritime Activities in the Baltic Sea 2018 (No. 152), Baltic Sea Environment Proceedings. Helsinki: Helsinki Commission.

Helle, E., Olsson, M., and Jensen, S. (1976). PCB levels correlated with pathological changes in seal uteri. Ambio 5, 261-262.

Hermannsen, L., Beedholm, K., Tougaard, J., and Madsen, P. T. (2014). High frequency components of ship noise in shallow water with a discussion of implications for harbor porpoises (Phocoena phocoena). J. Acoust. Soc. Am. 136, 1640-1653. doi: 10.1121/1.4893908

IAMMWG, Camphuysen, C. J., and Siemensma, M. L. (2015). A Conservation Literature Review for the Harbour Porpoise (Phocoena phocoena). JNCC Report No. 566. Peterborough: IAMMWG. Available online at: https://data.jncc.gov. uk/data/e3c85307-1294-4e2c-9864-f4dd0f195e1e/JNCC-Report-566-FINALWEB.pdf

ICES (2020). ICES Special Request Advice on Emergency Measures to Prevent Bycatch of Common Dolphin (Delphinus delphis) and Baltic Proper Harbour Porpoise (Phocoena phocoena) in the Northeast Atlantic. ICES

IUCN (2007). Species account by IUCN ssc cetacean specialist group; regional assessment by European mammal assessment team," in Phocoena phocoena. The IUCN Red List of Threatened Species 2007: e.T17027A6734714 (IUCN).
IUCN (2012). IUCN Red List Categories and Criteria. Version 3.1 Second edition. Prepared by the IUCN Species Survival Commission. As approved by the $51^{\text {st }}$ meeting of the IUCN Council. Gland. Available online at: https://www. iucnredlist.org/resources/categories-and-criteria (accessed February 9, 2000).

IWC (2002). Report of the Scientific Committee. J. Cetacean Res. Manage. 4(Suppl.):78.

IWC (2004). Annex L. report of the sub-committee on small cetaceans. J. Cetacean Res. Manag. 6, 315-334.

IWC (2020). Report of the scientific committee. J. Cetacean Res. Manage. 4 (Suppl): 130 .

Jaramillo-Legorreta, A. M., Cardenas-Hinojosa, G., Nieto-Garcia, E., RojasBracho, L., Thomas, L., Ver Hoef, J. M., et al. (2019). Decline towards extinction of Mexico's vaquita porpoise (Phocoena sinus). R. Soc. Open Sci. 6:190598. doi: $10.1098 /$ rsos. 190598

Jefferson, T. A., and Braulik, G. (2018). Phocoenoides dalli. The IUCN Red List of Threatened Species 2018: e.T17032A50370912. doi: 10.2305/IUCN.UK.2018-2.RLTS.T17032A50370912.en

Johansen, A. C. (1929). Om Dødeligheten Blandt Marsvin, Fisk og Større Krebsdyr i Farvandene Omkring Danmark Under Strenge Vintre (Beretning Til Ministeriet for Søfart og Fiskeri. Fra Den Danske. Biological Station No. 35.

Kauhala, K., Bäcklin, B.-M., Raitaniemi, J., and Harding, K. C. (2017). The effect of prey quality and ice conditions on the nutritional status of Baltic gray seals of different age groups. Mammal Res. 62, 351-362. doi: 10.1007/s13364-017-0329-x

Kesselring, T., Viquerat, S., Brehm, R., and Siebert, U. (2017). Coming of age: do female harbour porpoises (Phocoena phocoena) from the North sea and Baltic sea have sufficient time to reproduce in a human influenced environment? PLOS ONE 12:e0186951. doi: 10.1371/journal.pone.0186951

Kesselring, T., Viquerat, S., Brehm, R., and Siebert, U. (2018). Correction: coming of age: do female harbour porpoises (Phocoena phocoena) from the North sea and Baltic sea have sufficient time to reproduce in a human influenced environment? PLOS ONE 13:e0199633. doi: 10.1371/journal.pone.01 99633

Kinze, C. C. (1990). The Harbour Porpoise (Phocoena phocoena (L.)): Stock Identification and Migration Patterns in Danish and Adjacent Waters (Ph.D.). University of Copenhagen, Copenhagen.

Koschinski, S. (2001). Current knowledge on harbour porpoises (Phocoena phocoena) in the Baltic sea. Ophelia 55, 167-197. doi: 10.1080/00785326.2001.10409483

Lah, L., Trense, D., Benke, H., Berggren, P., Gunnlaugsson, P., Lockyer, C., et al. (2016). Spatially explicit analysis of genome-wide SNPs detects subtle population structure in a mobile marine mammal, the harbor porpoise. PLOS ONE 11:e0162792. doi: 10.1371/journal.pone.0162792

Larsson, K. (2016). Sjöfart Och Naturvärden Vid Utsjöbankar I Centrala Östersjön - Havsplanering Kan Reducera Konflikter (No. Havs-och Vattenmyndighetens Rapport 2016:24). Gothenburg: Swedish Agency for Marine and Water Management.

Learmonth, J. A, Murphy, S., Luque, P. L., Reid, R. J., Patterson, I. A. P., Brownlow, A., et al. (2014). Life history of harbour porpoises (Phocoena phocoena) in Scottish (UK) waters. Mar. Mammal Sci. 30, 1427-1455. doi: $10.1111 / \mathrm{mms} .12130$

Lindroth, A. (1962). Baltic salmon fluctuations 2: Porpoise and salmon (No. 44). Stockholm: Reports of the Institute of Freshwater Research Drottningholm.

Lockyer, C. (1995). "Investigations of aspects of the life history of the Harbour Porpoise, Phocoena phocoena, in British waters," in Biology of the Phocoenids: 189-197. Special Issue 16, eds A. Bjørge and G. P. Donovan (Cambridge: International Whaling Commission).

Lõugas, L. (1999). Postglacial development of fish and seal faunas in the Eastern Baltic water systems. Archäol. Eurasien 6, 185-200.

Matczak, M., Meyer, N. K., Ooms, E., Schroder, L., Vološina, M., and Warmelink, H. (2018). "QUO VADIS Exploring the future of shipping in the Baltic sea," in Baltic LINes - Coherent Linear Infrastructures in Baltic Maritime Spatial Plans, 2018-07.

Mikhalev, Y. A. (2005). The peculiarities of the distribution of the harbour porpoise, Phocoena phocoena relicta (Cetacea) in the Black sea. Vestnik Zool. 39, 25-35. Available online at: http://dspace.nbuv.gov.ua/handle/123456789/ 3389 
Møhl-Hansen, U. (1954). Investigations on reproduction and growth of the porpoise (Phocaena phocaena (L.)) from the Baltic. Viddenskaplige meddelelser fra den dan. Naturhistoriske Foren. 116, 369-396.

Murphy, S., Barber, J. L., Learmonth, J. A., Read, F. L., Deaville, R., Perkins, M. W., et al. (2015). Reproductive failure in UK harbour porpoises Phocoena phocoena: legacy of pollutant exposure? PloS ONE 10:e131085. doi: 10.1371 /journal.pone.0131085

NAMMCO (2013). North Atlantic Marine Mammal Commission Annual Report 2013. Tromsø: Scientific Committee Working Group on Harbour Porpoises.

NAMMCO (2017). Meeting NAMMCO Scientific Committee Working Group on By-catch. Copenhagen. Available online at: https://nammco.no/topics/scworking-group-reports/

NAMMCO (2019). Report of the NAMMCO Scientific Committee Working Group on Harbour Porpoise. Copenhagen: NAMMCO.

NAMMCO and the Norwegian Institute of Marine Research (NAMMCO and IMR) (2019). Report of Joint IMR/NAMMCO International Workshop on the Status of Harbour Porpoises in the North Atlantic. Tromsø. Available online at: https://nammco.no/wp-content/uploads/2020/03/finalreport_hpws_2018_rev2020.pdf

Nielsen, N. H., and Heide-Jørgensen, M. P. (2013). Catch Statistics for Harbour Porpoises in West Greenland Including Correction for Unreported Catches. NAMMCO SC/20/HP/06 Harbour porpoise working group November 2013.

Nielsen, N. H., Teilmann, J., Sveegaard, S., Hansen, R. G., Sinding M.-H. S., Dietz, R., et al. (2018). Oceanic movements, site fidelity and deep diving in harbour porpoises from Greenland show limited similarities to animals from the North Sea. Mar. Ecol. Prog. Ser. 597, 259-272. doi: 10.3354/meps 12588

Nunny, L., Carlén, I., and Simmonds, M. (2020). Mammal Quiz - Preliminary Results. Available online at: https://ccb.se/results-from-the-mammal-quiz/

Oguz, T., and Gilbert, D. (2007). Abrupt transitions of the top-down controlled Black sea pelagic ecosystem during 1960-2000: evidence for regime-shifts under strong fishery exploitation and nutrient enrichment modulated by climate-induced variations. Deep-Sea Res. Part I 54, 220-242. doi: 10.1016/j.dsr.2006.09.010

Øien, N., and Haug, T. (2017). Norway - Progress Report on Marine Mammals 2017 (No. NAMMCO/26/NPR-N-17). NAMMCO.

Österblom, H., Hansson, S., Larsson, U., Hjerne, O., Wulff, F., Elmgren, R., et al. (2007). Human-induced trophic cascades and ecological regime shifts in the Baltic sea. Ecosystems 10, 877-889. doi: 10.1007/s10021-007-9069-0

Otterlind, G. (1976). The Harbour Porpoise (Phocoena phocoena) Endangered in Swedish Waters. International Council for the Exploration of the Sea.

Pennisi, E. (2017). After failed rescue effort, rare porpoise in extreme peril. Science 358:851. doi: 10.1126/science.358.6365.851

Read, A. J., Waples, D. M., Urian, K. W., and Swanner, D. (2003). Fine-scale behaviour of bottlenose dolphins around gillnets. Proc. R. Soc. Lond. B Biol. Sci. 270, S90-S92. doi: 10.1098/rsbl.2003.0021

Rian, M. B., Vike-Jonas, K., Gonzalez, S. V., Ciesielski, T. M., Venkatraman, V., Lindstrom, U., et al. (2020). Phthalate metabolites in harbor porpoises (Phocoena phocoena) from Norwegian coastal waters. Environ. Int. 137:105525. doi: 10.1016/j.envint.2020.105525

Rohling, E. J., Abu-Zieb, R., Casford, J. L. S., Hayes, A., and Hoogaaker, B. A. A. (2009). "The marine environment: present and past," in The Physical Geography of the Mediterranean, ed J. Woodward (Oxford: Oxford University Press Inc), 33-67.

Rojas-Bracho, L., Reeves, R. R., and Jaramillo-Legorreta, A. (2006). Conservation of the vaquita Phocoena sinus. Mammal Rev. 36, 179-216. doi: 10.1111/j.1365-2907.2006.00088.x

Rojas-Bracho, L., and Taylor, B. L. (2017). Phocoena Sinus. The IUCN Red List of Threatened Species 2017: e.T17028A50370296. doi: 10.2305/IUCN.UK.2017-2.RLTS.T17028A50370296.en

Ropelewski, A. (1957). Morswin (Phocoena phocoena L.) jako przylow w Polskim rybolowstwie Baltyckim (The common porpose (Phocoena phocoena L.) as a by-catch in Polish Baltic Fisheries). Pr.Morskiego Intytutu RybackiegoWGdyn. 9, 427-437.

Rosel, P. E., Frantzis, A., Lockyer, C., and Komnenou, A. (2003). Source of Aegean sea harbour porpoises. Mar. Ecol. Prog. Ser. 247, 257-261. doi: $10.3354 /$ meps 247257

SAMBAH (2016). Final Report for LIFE+ Project SAMBAH LIFE08 NAT/S/000261 Covering the Project Activities From 01/01/2010 to 30/09/2015 (No. Reporting
Date 29/02/2016). Available online at: http://www.sambah.org/SAMBAHFinal-Report-FINAL-for-website-April-2017.pdf

Sequeira, M. (1996). Harbour porpoises Phocoena phocoena in Portuguese waters. Rep. Int. Whal. Comm. 46, 583-586.

Siebert, U., Pawliczka, I., Benke, H., von Vietinghoff, V., Wolf, P., Pilāts, V., et al. (2020). Health assessment of harbour porpoises (Phocoena phocoena) from Baltic area of Denmark, Germany, Poland and Latvia. Environ. Int. 143:105904. doi: 10.1016/j.envint.2020.105904

Skóra, K. E., Pawliczka, I., and Klinowska, M. (1988). Observations of the harbour porpoise (Phocoena phocoena) on the Polish Baltic coast. Aquat. Mamm. $14,113-119$.

Snape, R. T. E., Broderick, A. C., Çiçek, B. A., Fuller, W. J., Tregenza, N., Witt, M. J., et al. (2018). Conflict between dolphins and a data-scarce fishery of the European Union. Hum. Ecol. 46, 423-433. doi: 10.1007/s10745-018-9989-7

Sommer, R. S., Pasold, J., and Schmölcke, U. (2008). Post-Glacial immigration of the harbour porpoise (Phocoena phocoena) into the Baltic sea. Boreas 37, 458-464. doi: 10.1111/j.1502-3885.2008. 00034.x

STECF (2019). Scientific, Technical and Economic Committee for Fisheries (STECF) - 61st Plenary Meeting Report (PLEN-19-02). Luxembourg: STECF; Publications Office of the European Union.

Sveegaard, S., Galatius, A., Dietz, R., Kyhn, L., Koblitz, J. C., Amundin, M., et al. (2015). Defining management units for cetaceans by combining genetics, morphology, acoustics and satellite tracking. Glob. Ecol. Conserv. 3, 839-850. doi: 10.1016/j.gecco.2015.04.002

Tanabe, S., Madhusree, B., Öztürk, A. A., Tatsukawa, R., Miyazaki, N., Özdamar, E., et al. (1997). Persistent organochlorine residues in harbour porpoise (Phocoena phocoena) from the Black sea. Mar. Pollut. Bull. 34, 338-347. doi: 10.1016/S0025-326X(96)00081-1

Taylor, B., and Gerrodette, T. (1993). The uses of statistical power in conservation biology: the vaquita and northern spotted owl. Conserv. Biol. 7, 489-500. doi: 10.1046/j.1523-1739.1993.07030489.x

Taylor, B. L., Wells, R. S., Olson, P. A., Brownell, R. L., Jr., Gulland, F. M. D., Read, A. J., et al. (2019). Likely annual calving in the vaquita, Phocoena sinus: a new hope? Mar. Mam. Sci. 35, 1603-1612. doi: 10.1111/mms. 12595

Teilmann, J., and Dietz, R. (1998). Status of the harbour porpoise in Greenland. Polar Biol. 19, 211-220. doi: 10.1007/s003000 050237

Teilmann, J., and Sveegaard, S. (2019). "Porpoises the world over: diversity in behavior and ecology," in Ethology and Behavioral Ecology of Odontocetes, ed B. Würsig (Cham: Springer), 449-464.

Tolley, K. A., Víkingsson, G. A., and Rosel, P. E. (2001). Mitochondrial DNA sequence variation and phylogeographic patterns in harbour porpoises (Phocoena phocoena) from the North Atlantic. Conserv. Genet. 2, 349-361. doi: 10.1023/A:1012561811074

Tonay, A. M., and Dede, A. (2013). First stranding record of a harbour porpoise (Phocoena phocoena) in the Southern Aegean Sea. J. Black Sea Mediterranean Environ. 19, 132-137. Available online at: http://blackmeditjournal.org/ volumes-archive/vol19-2013/vol-19-2013-no-1/first-stranding-record-of-aharbour-porpoise-phocoena-phocoena-in-the-southern-aegean-sea/

Tonay, A. M., Dede, A., Maraci, Ö., and Bilgin, R. (2012a). A preliminary genetic study on the harbour porpoise (Phocoena phocoena) in the Turkish Seas. J. Black Sea Mediterranean Environ. 18, 83-89. Available online at: http:// blackmeditjournal.org/volumes-archive/vol18-2012/vol-18-2012-no-1/apreliminary-genetic-study-on-the-harbour-porpoise-phocoena-phocoenain-the-turkish-seas/

Tonay, A. M., Dede, A., Öztürk, A. A., Ercan, D., and Fernández, A. (2012b). Unusual mass mortality of cetaceans on the coast of the Turkish Western Black Sea in summer 2009. J. Black Sea Mediterranean Environ. 18, 67-75. Available online at: http://blackmeditjournal.org/volumes-archive/vol18-2012/ vol-18-2012-no-1/unusual-mass-mortality-of-cetaceans-on-the-coast-ofthe-turkish-western-black-sea-in-summer-2009/

Van Waerebeek, K., Apaza, M., Reyes, J. C., Alfaro-Shgueto, J., Santillan, L., Barreda, E., et al. (2018). Beach-cast Small Cetaceans Bear Evidence of Continued Catches and Utilization in Coastal Peru, 2000-2017. Submitted to the Scientific Committee of the International Whaling Commission and available from the International Whaling Commission. 
Viaud-Martínez, K. A., Martínez Vergara, M., Gol'din, P. E., Ridoux, V., Öztürk, A. A., Öztürk, B., et al. (2007). Morphological and genetic differentiation of the Black sea harbour porpoise Phocoena phocoena. Mar. Ecol. Prog. Ser. 338, 281-294. doi: 10.3354/meps338281

Vishnyakova, K., and Gol'din, P. (2015). Seasonality of strandings and bycatch of harbour porpoises in the sea of Azov: the effects of fisheries, weather conditions, and life history. ICES J. Mar. Sci. 72, 981-991. doi: 10.1093/icesjms/fsu192

Wang, D., Turvey, S. T., Zhao, X., and Mei, Z. (2013). Neophocaena asiaeorientalis ssp. Asiaeorientalis. The IUCN Red List of Threatened Species 2013: e.T43205774A45893487. doi: 10.2305/IUCN.UK.2013-1.RLTS.T43205774A45893487.en

Wang, J. Y., and Reeves, R. (2017a). Neophocaena Asiaeorientalis. The IUCN Red List of Threatened Species 2017: e.T41754A50381766. doi: 10.2305/IUCN.UK.2017-3.RLTS.T41754A50381766.en

Wang, J. Y., and Reeves, R. (2017b). Neophocaena Phocaenoides. The IUCN Red List of Threatened Species 2017: e.T198920A50386795. doi: 10.2305/IUCN.UK.2017-3.RLTS.T198920A50386795.en

Williams, J., David, R. S., Curnick, J., Barber, L., Brownlow, A., Davison, N. J., et al. (2020) Juvenile harbor porpoises in the UK are exposed to a more neurotoxic mixture of polychlorinated biphenyls than adults. Sci. Total Environ. 708:134835. doi: 10.1016/j.scitotenv.2019.134835

Wisniewska, D.M., Johnson, M., Teilmann, J., Rojano-Doñate, L., Shearer, J., Sveegaard, S. et al. (2016). Ultra-high foraging rates of harbor porpoises make them vulnerable to anthropogenic disturbance. Curr. Biol. 26, 1441-1446. doi: 10.1016/j.cub.2016.03.069
Wisniewska, D. M., Johnson, M., Teilmann, J., Rojano-Doñate, L., Shearer, J., Sveegaard, S., et al. (2018a). Response to "resilience of harbor porpoises to anthropogenic disturbance: must they really feed continuously?" Mar. Mammal Sci. 34, 265-270. doi: 10.1111/mms. 12463

Wisniewska, D. M., Johnson, M., Teilmann, J., Siebert, U., Galatius, A., Dietz, R., et al. (2018b). High rates of vessel noise disrupt foraging in wild harbour porpoises (Phocoena phocoena). Proc. R. Soc. B Biol. Sci. 285:20172314. doi: $10.1098 / \mathrm{rspb} .2017 .2314$

Zaharieva, Z., Yordanov, N., Racheva, V., and Delov, V. (2019). The effect of pingers on cetaceans bycatch and target catch in the turbot gillnets in Bulgarian Black sea. ZooNotes. 150, 1-4. Available online at: http://www.zoonotes.bio. uni-plovdiv.bg/ZooNotes_2019/ZooNotes_2019_Full.pdf

Conflict of Interest: The authors declare that the research was conducted in the absence of any commercial or financial relationships that could be construed as a potential conflict of interest.

Copyright $\odot 2021$ Carlén, Nunny and Simmonds. This is an open-access article distributed under the terms of the Creative Commons Attribution License (CC BY). The use, distribution or reproduction in other forums is permitted, provided the original author(s) and the copyright owner(s) are credited and that the original publication in this journal is cited, in accordance with accepted academic practice. No use, distribution or reproduction is permitted which does not comply with these terms. 